\title{
Lipid production and molecular studies of Anabaena torulosa treated with different types of stress
}

\author{
Olfat M. A. Salem ${ }^{1 *}$, IbtisamA.Hammad ${ }^{1}$, Fatma A.Badea ${ }^{1}$, Nagui A. \\ Abdel Khalek ${ }^{2}$ and Khaled A.Selim ${ }^{2}$ \\ ${ }^{1}$ Botany and microbiology department, Faculty of Science, Helwan \\ University, Cairo, Egypt. \\ ${ }^{2}$ Central Metallurgical Research and Development Institute, Cairo, Egypt.
}

\begin{abstract}
:
Lipid production in terms of oil percentage and fatty acid composition of Anabaena torulosa which was identified morphologically and genetically was studied to determine its ability for biodiesel production, in response to salinity, nitrogen and phosphorus starvation stress; salinity ranging from 50 to $250 \mathrm{mM} \mathrm{NaCl}$, nitrogen and phosphorus regime $\left(50 \%, \mathrm{NO}_{3}-\mathrm{N}, 50 \% \mathrm{PO}_{4}-\mathrm{P}\right.$ of $\mathrm{BG} 11$ media). The results indicated that there was change in physiological behavior under these different stresses and illustration of these differences genetically. The results of oil analysis revealed that the lipid production increased when nitrogen and phosphorus decrease $(68.83 \%$ and $160.97 \%$ respectively) and $200 \mathrm{mM}$ of $\mathrm{NaCl}$ increase oil content by $120 \%$. GC/MS analysis of fatty acid composition revealed that methyl linoleate is the main constituent of fatty acids ester $57.9 \%$ which classified as a biodiesel due to its long methyl ester chain and is also used as a fuel in standard diesel engines. All these results explained genetically by using RAPD technique which revealed new bands appeared and other bands disappeared. DNA sequence was changed leading to DNA polymorphism $41.25 \%$. Also, the DNA pattern indicated that stress of nitrogen and phosphorus were more related to control, while the other stresses (salinity and combined stresses) caused more changes comparing to control. So that stress changes in physiology was confirmed genetically.
\end{abstract}

Keywords: Anabaena torulosa, lipid, fatty acids, salinity, RAPD.

\section{Introduction}

Many scientists in recent years turn their attention to the use of cyanobacteria as excellent organisms for renewable biodiesel production, it has high oil yield, and easily grown in non-arable land. Because the production of biodiesel depends primarily on the amount of oils found in these microorganisms, so that; the scientists went to study the factors that affect the production of oils. 
There are a lot of stress conditions that affect the oil production efficiency of the algal cells by increasing their oil content which includes; nitrogen and phosphorus starvation, high salinity stress and light wave lengths stress. A lot of studies carried out with such techniques in microalgae (Hu et al., 2008; Salem et al., 2013;Elsayed and Salem, 2016). Nirupam et al. (2012) showed that cyanobacteria; such as Lyngbya majuscula, Phormidium valderianum, Synechocystis pevalekii and chlorophytes such as Chlorella vulgaris, Rhizoclonium riparium, Rhizoclonium africanum, Spirogyra orientalis and Cladophora crystallina, having suitable fatty acid composition were identified for biodiesel production.

Salehzadeh and Naeemi (2017) proved that Anabaena is one of many promising species of Cyanobacteria which produced a mixture of saturated and unsaturated fatty acids that exceeded $40 \%$ of the weight of dry biomass, where Palmitic acid was defined after GC-Mass analysis of oil extracted from the A. variabilis, as a fatty acid that can be used as biodiesel. Nevertheless, nitrogen stress might not always promote lipid induction but can result in change in lipid composition as well with accumulation of fatty acids (Rodolfi $\boldsymbol{e t}$ al., 2009; Tang et al., 2011).

Most species belonging to Cyanobacteria have long been known for their taxonomic complexity that basically depends on the morphological data. Hence, several generic lineages needed to be re-circumscribed to promote the enhancement of poor informative morphological data with molecular based data. Use of molecular markers for identification of cyanobacteria in diverse has gained considerable significance. Molecular datasets can effectively complement morphological characterization. However, Wacklin et al. (2009) and Chioet al. (2018) suggested classification of Dolichospermum hangangense using 16SrRNA phylogenetic analysis which confirmed morphology-based classification.

Other molecular markers such as restriction fragment length polymorphism (RFLP) and 16SrRNA to characterize Anabaena strains (Prasannaet al., 2006). Random amplified polymorphic DNA (RAPD) has also been used to differentiate among different Cyanobacteria species including Anabaena and Nostoc (Perumalet al., 2009; Chakdar and Pabbi, 2017). These molecular techniques have been employed in phylogenetic analysis and characterization of cyanobacterial diversity. The presence of highly conserved repetitive sequences in 
the genomes of microorganisms makes them highly useful for strain differentiation and diversity analysis.

RAPD-PCR is a PCR based technique for identifying genetic variation by using single arbitrary primer in a PCR reaction resulting in the amplification of many discrete DNA products. This procedure detects nucleotide sequence polymorphism in a DNA amplification based assay using a single primer of arbitrary nucleotide sequence (Okoreet al., 2017).

In the present study, molecular analyses were performed with 16SrRNA and 16S-23S ITS sequences to conform the morphological identification of $A$. torulosa obtained from Dr. Olfat M.A Salem. (Phycology lab - Helwan University) and also the present study aimed to assess the effects of nitrogen was and phosphorus deficiency and salinity stress on lipid production and their corresponding fatty acid profiling of Anabaena, finally we assess the effect of these types of stresses on genetic markers of the species using RAPD.

\section{Materials and Methods}

\section{Organism and growth conditions}

Anabaena torulosa isolated from Wadi El-Natron (longitudes $30^{\circ} 18^{\prime} 50^{\prime \prime} \mathrm{E}$ and latitudes $30^{\circ} 24^{\prime} 10^{\prime \prime} \mathrm{N}$ ) was purified by algae lab, Faculty of Science, Helwan University. It was identified morphologically by light microscopy (Olympus IX, Tokyo, Japan), and the optimization growth conditioned were examined; It was cultivated in BG11 medium (Allen, 1968). For the production of biomass, exponentially growing algae culture was transferred into fresh sterile medium [10\% (v/v) of inoculums]. Cultures were illuminated by tubular fluorescent lamps with light intensity of $25 \mu \mathrm{mol}$ photons $\mathrm{m}^{-2} \mathrm{~s}^{-1}$. Examination of the species growth optimization takes place as follow; $\mathrm{pH}$ intervals from 4,5,6,7,8,9 to identify the optimum initial $\mathrm{pH}$, photoperiod (light/ dark) intervals (continuous light, $12 \mathrm{~h}: 12 \mathrm{~h}, 16: 8)$, the different growth temperatures $\left(15,20,25,30,35^{\circ} \mathrm{C}\right)$. The optimum incubation period was examined by measuring the organism growth every 3 days for 30 days. All experiments mentioned above were performed in triplicates using $1 \mathrm{~L}$ Erlenmeyer flasks. The growth of the organism was determined by dry weight estimation. 


\section{Stress experiments}

The experiments were designed by inoculation of $A$. torulosa in BG11medium with optimized growth condition (as mentioned above) in Three sterile Erlenmeyer flasks $(500 \mathrm{ml})$ each containing $200 \mathrm{ml}$ medium treated as follow: strain cultured in BG11 medium (control), three types of stress were selected; BG11 media with $50 \% \mathrm{NaNO}_{3}$, media with $50 \% \mathrm{~K}_{2} \mathrm{HPO}_{4} .3 \mathrm{H}_{2} \mathrm{O}$, Salinity stress with different concentrations of $\mathrm{NaCl}(50,100,150,200$ and $250 \mathrm{mM})$ and finally the combined stress(media with $50 \% \mathrm{~N}, 50 \% \mathrm{P}$ and $200 \mathrm{mM} \mathrm{NaCl}$ ).

\section{Oil extraction and analysis}

The oil extraction takes place according to Halim et al. (2011). A mixture of $\mathrm{n}$-hexane and isopropanol (3:2) was added to $4 \mathrm{~g}$ of dried $A$. torulosa powder. The extraction mixtures were agitated at $800 \mathrm{rpm}$ in shaking incubator (LSI-30 16/LSI-30 16R) for 7.5 hs. Cell residue was removed by filtering through Whatman GF/C paper. The filtrate was transferred into a separating funnel and sufficient hexane and water (approximately $40 \mathrm{ml}$ each) were added to induce biphasic layering. After settling, the solvent mixture was partitioned into two distinct phases: a top hexane layer containing most of the extracted lipids and a bottom isopropanol layer containing most of the co-extracted non-lipid contaminants. The hexane phase was collected to enable gravimetric quantification of the lipid extract. The most effective stress treatment and the control were analyzed by GC/MS.

\section{GC/MS fatty acid composition analysis:}

Preparation of fatty acids methyl esters takes place according to Rozes $\boldsymbol{e t}$ al. (1993); $100 \mu \mathrm{l}$ of oil sample were added in the test tube and dissolved in $0.5 \mathrm{ml}$ hexane, and then sodium methoxide $(0.5 \mathrm{ml})$ was added and mixed for $1 \mathrm{~min}$. The upper phase (hexane layer) was removed and injected into the chromatography. The GC-MS system (Agilent Technologies) was equipped with gas chromatograph (7890B) and mass spectrometer detector (5977A) at Central Laboratories Network, National Research Centre, Cairo, Egypt. The GC was equipped with HP-5MS column $(30 \mathrm{~m} \times 0.25 \mathrm{~mm}$ internal diameter and $0.25 \mu \mathrm{m}$ film thickness). Analyses were carried out using helium as the carrier gas at a 
flow rate of $1.0 \mathrm{ml} / \mathrm{min}$ at a split ratio of $1: 10$, injection volume of $1 \mu 1$ and the following temperature program: $50{ }^{\circ} \mathrm{C}$ for $1 \mathrm{~min}$; rising at $20^{\circ} \mathrm{C} / \mathrm{min}$ to $200{ }^{\circ} \mathrm{C}$ and held for $5 \mathrm{~min}$; rising at $3{ }^{\circ} \mathrm{C} / \mathrm{min}$ to $230{ }^{\circ} \mathrm{C}$ and held for $23 \mathrm{~min}$. The injector and detector were held at $250^{\circ} \mathrm{C}$. Mass spectra were obtained by electron ionization (EI) at $70 \mathrm{eV}$ and using a spectral range of m/z 20-550 and solvent delay $1.8 \mathrm{~min}$. Identification of different constituents was determined by comparing the spectrum fragmentation pattern with those stored in Wiley and NIST Mass Spectral Library data.

\section{DNA extraction and sequencing.}

\section{Genomic DNA extraction:-}

Genomic DNA was extracted according to Rogers and Bendish, 1998 from $0.5 \mathrm{~g}$ dried algal biomass by using CTAB method after minor modifications (incubation $40 \mathrm{~min}$ instead of one hour). The quantity of DNA was estimated by comparison with known standards in ethidium bromide stained $0.8 \%$ agarose gels.

\section{Identification using amplification of $16 \mathrm{~S}$ rRNA gene of Anabaena}

16S rRNA gene fragment was amplified with universal primers E528F (5' -CGGTAATTCCAGCTCC-3') and Univ1517 (5' ACGGCTACCTTGTTACGACTT-3') (Lyraet al., 1997; Chakdar and Pabbi, 2017). The polymerase chain reaction was carried out in a final volume of $25 \mu 1$ containing 2X RED master mix, 16S primers (FD1 and RP2) 2.5 pmol each and $50 \mathrm{ng}$ of genomic DNA. Amplification was carried out in Biometrathermocycler programmed for initial denaturation $\left(94^{\circ} \mathrm{C}\right.$ for 5 $\mathrm{min})$ followed by 35 cycles, composed of denaturation $\left(94^{\circ} \mathrm{C}\right.$ for $\left.30 \mathrm{~s}\right)$, primer annealing $\left(64^{\circ} \mathrm{C}\right.$ for $\left.45 \mathrm{~s}\right)$, extension $\left(72^{\circ} \mathrm{C}\right.$ for $\left.2 \mathrm{~min}\right)$ followed by a final extension of $7 \mathrm{~min}$ at $72^{\circ} \mathrm{C}$ and subsequent cooling at $4{ }^{\circ} \mathrm{C}$ temperature.

Amplified PCR product was separated along with a molecular weight marker (GeneRuler, $1 \mathrm{~kb}$, Fermentas, USA) by electrophoresis on $1.2 \%$ agarose (Vivantis, USA) gel run in $1 \mathrm{X}$ TBE (Tris-Borate-EDTA) buffer, stained with ethidium bromide for a period of $1 \mathrm{~h}$ at $100 \mathrm{~V}$. These were visualized under UV light and gel photographs using VilberLourmat Gel 
Documentation System. The amplification product sizes were estimated using BIO-RAD Quantitiy One software.

The DNA band was extracted using a QIA quick Gel Extraction Kit following the manufacture instructions. The product was sequenced in GATC Company for sequencing which uses the ABI 3730xl DNA sequencer by using forward and reverse sequences, by combining the traditional Sanger with the new 454 technology. A nucleotide blast search was performed with the sequences using sequence alignment by NCBI blast and Geneious. Pro.v4.8.4 software.

\section{RAPD-PCR and electrophoretic analysis}

This molecular technique was performed for Anabaena treated with different treatments comparing with control. The RAPD-PCR assay was carried out at Genetic laboratory, Botany and Microbiology Department, Faculty of Science, Helwan University. The assay was carried out using 4 RAPD oligo nucleotide primers (OPA-11, OPA-13, CRA-22 and Hip-TG). The standard, optimized PCR was performed in a total volume of $25 \mu 1$ containing $1 \mu \mathrm{l}$ of each primer, $50 \mu \mathrm{g} / \mathrm{ml}$ of DNA and $12.5 \mu \mathrm{l}$ of $2 \mathrm{X}$ RED Taq PCR master mix. This bioassay was performed using Biometrathermocycler. PCR programing was as follow: initial denaturation $\left(94^{\circ} \mathrm{C}\right.$ for $\left.5 \mathrm{~min}\right)$ followed by 40 cycles, of denaturation $\left(94^{\circ} \mathrm{C}\right.$ for $\left.30 \mathrm{~s}\right)$, primer annealing $\left(32-34^{\circ} \mathrm{C}\right.$ for $45 \mathrm{~s}$ according to the primer), extension $\left(72^{\circ}\right.$ $\mathrm{C}$ for $1 \mathrm{~min}$ ) followed by a final extension of $10 \mathrm{~min}$ at $72^{\circ} \mathrm{C}$ and cooling at $4^{\circ} \mathrm{C}$ temperature. The product was examined on $1.2 \%$ Agarose gel electrophoresis with ethidium bromide. After running, the gels were photographed under UV radiation in gel documentation system.

For amplification of the $16 \mathrm{~min}$. whole genomic DNA was extracted using the MoBio Ultra Clean Microbial DNA Isolation Kit (MoBio Laboratories Inc., Carlsbad, CA, USA) according to the manufacturer's instructions. DNA bands were examined on a $1 \%$ agarose gel run at 100 volts for 40-23S rRNA gene product, previously published primer pairs were E528F (5'-CGGTAATTCCAGCTCC-3) Univ1517 (5' GCTACCTTGTTACGACTT-3') (Lyra et al., 1997 and Chakdar and 
Pabbi, 2017). Genomic DNA was extracted according to Rogers and Bendish, 1998 from $0.5 \mathrm{~g}$ dried algal biomass by using CTAB method after minor modifications (incubation $40 \mathrm{~min}$ instead of one hour). The quantity of DNA was estimated by comparison with known standards in ethidium bromide stained $0.8 \%$ agarose gels.

\section{Statistical analysis}

Hierarchical cluster analysis was made by the complete linkage method with genetic distance measure for evaluating the relatives among the different studied treated Anabeana. The data was analyzed using Bio Rad Quantity One (Shuaib et al., 2007).

\section{Results}

Anabaena torulosa was cultured in BG 11 media. The optimizing condition experiments indicated that optimum $\mathrm{pH}$ was 7.0 and the optimum incubation period was 27 days at $25 \pm 1{ }^{\circ} \mathrm{C}, 18 / 6$ light/dark cycle with light intensity of $25 \mu \mathrm{mol}$ photons $\mathrm{m}^{-2} \mathrm{~s}^{-1}$. The oil content of cells grow in the control and treated cultures was measured, and the oil percentage gave some changes from control as shown in Table (1) phosphorus stress (T2) showed the highest percentage of increase in oil percentage $160.97 \%$, followed by salinity stress with $200 \mathrm{mM} \mathrm{NaCl}(120.86 \%)$, followed by $250 \mathrm{mM} \mathrm{NaCl}(83.58 \%)$, and finally nitrogen stress giving $68.83 \%$ increase in oil, The combined stress (T8) had $44.1 \%$

The composition and distribution of fatty acidsanalyzed by GC-MS in A. torulosa grown in BG11 medium (control) and treated with $50 \% \quad \mathrm{~K}_{2} \mathrm{HPO}_{4}$ (The most effective stress treatment)are represented in Table (2); most fatty acids were unsaturated, although saturated fatty acids were detected as well. As can be seen, linoleic acid was the major fatty acid in the lipids extracted; the methyl linoleate represent $57.09 \%$ in A. torulosa cultured in control media and $56.73 \%$ in stress medium. Elaidic acid methyl ester (isomer of oleic acid) followed linoleate and record $23.91 \%$ in control and $23.53 \%$ in treated organism. 
Table (1): The oil percentage of $A$. torulosa cultured in BG11 medium under different stress conditions

\begin{tabular}{|l|c|c|c|}
\hline & Treatments & $\begin{array}{c}\text { Oil Percentage } \\
\text { (mean } \pm \text { SD) }\end{array}$ & $\begin{array}{c}\text { Percentage of } \\
\text { increase }\end{array}$ \\
\hline BG11 media & Control & $15.53 \pm 0.11$ & - \\
\hline Nitrogen stress & $\mathrm{T} 1\left(50 \% \mathrm{NaNO}_{3}\right)$ & $26.22 \pm 0.24$ & 68.83 \\
\hline $\begin{array}{l}\text { Phosphorus } \\
\text { stress }\end{array}$ & $\mathrm{T} 2\left(50 \% \mathrm{~K}_{2} \mathrm{HPO}_{4} .3 \mathrm{H}_{2} \mathrm{O}\right)$ & $40.53 \pm 0.25$ & 160.97 \\
\hline \multirow{3}{*}{$\begin{array}{l}\text { Salinity stress } \\
\text { mM NaCl }\end{array}$} & $\mathrm{T} 3(50)$ & $17.19 \pm 0.41$ & 10.68 \\
\cline { 2 - 4 } & $\mathrm{T} 4(100)$ & $19.62 \pm 0.25$ & 26.33 \\
\cline { 2 - 4 } & $\mathrm{T} 5(150)$ & $22.93 \pm 0.14$ & 47.64 \\
\cline { 2 - 4 } & $\mathrm{T} 6(200)$ & $34.3 \pm 0.01$ & 120.86 \\
\hline \multirow{2}{*}{ Combined stress } & $\mathrm{T} 7(250)$ & $28.51 \pm 0.26$ & 83.58 \\
\hline
\end{tabular}

Table (2): Fatty acid profile of $A$. torulosa cultured in BG11 medium (control) and treated with $50 \% \mathrm{~K}_{2} \mathrm{HPO}_{4}$

\begin{tabular}{|c|c|c|c|c|c|c|}
\hline \multirow{2}{*}{$\begin{array}{c}\text { Type of } \\
\text { fatty acid }\end{array}$} & $\begin{array}{c}\text { Fatty Acid } \\
\text { Name }\end{array}$ & $\begin{array}{c}\text { Lipid } \\
\text { number }\end{array}$ & $\begin{array}{c}\text { Common } \\
\text { name }\end{array}$ & Formula & control & $\begin{array}{c}\text { 50\% } \\
\mathbf{K}_{2} \mathbf{H P O}_{\mathbf{4}}\end{array}$ \\
\hline \multirow{2}{*}{ Saturated } & $\begin{array}{c}\text { Hexadecanoic } \\
\text { acid, methyl } \\
\text { ester }\end{array}$ & $\mathrm{C} 16: 0$ & $\begin{array}{c}\text { Palmitic } \\
\text { acid methyl } \\
\text { ester }\end{array}$ & $\mathrm{C}_{17} \mathrm{H}_{34} \mathrm{O}_{2}$ & 14.31 & 15 \\
\cline { 2 - 7 } & $\begin{array}{c}\text { Octadecanoic } \\
\text { acid, methyl } \\
\text { ester }\end{array}$ & $\mathrm{C} 18: 0$ & $\begin{array}{c}\text { Stearic acid } \\
\text { methyl ester }\end{array}$ & $\mathrm{C}_{19} \mathrm{H}_{38} \mathrm{O}_{2}$ & 3.79 & 3.89 \\
\hline $\begin{array}{c}9,12- \\
\text { Poly }\end{array}$ & $\begin{array}{c}\text { Octadecadienoic } \\
\text { acid (Z, Z)-, } \\
\text { methyl ester }\end{array}$ & $\mathrm{C} 18: 2$ & $\begin{array}{c}\text { Linoleic } \\
\text { acid methyl } \\
\text { ester }\end{array}$ & $\mathrm{C}_{19} \mathrm{H}_{34} \mathrm{O}_{2}$ & 57.09 & 56.73 \\
\hline $\begin{array}{c}\text { Mono } \\
\text { Unsaturated }\end{array}$ & $\begin{array}{c}\text { 9-Octadecenoic } \\
\text { acid, methyl } \\
\text { ester, (E)- }\end{array}$ & $\mathrm{C} 18: 1(\mathrm{n}-9)$ & $\begin{array}{c}\text { Elaidic acid } \\
\text { methyl ester }\end{array}$ & $\mathrm{C}_{19} \mathrm{H}_{36} \mathrm{O}_{2}$ & 23.91 & 23.53 \\
\hline $\begin{array}{c}\text { Mono } \\
\text { Unsaturated }\end{array}$ & $\begin{array}{c}\text { 9-Octadecenoic } \\
\text { acid (Z)-, } \\
\text { methyl ester }\end{array}$ & $\mathrm{C} 18: 1(\mathrm{n}-9)$ & $\begin{array}{c}\text { Oleic acid } \\
\text { methyl ester }\end{array}$ & $\mathrm{C}_{19} \mathrm{H}_{36} \mathrm{O}_{2}$ & 0.91 & 0.85 \\
\hline
\end{tabular}

Egyptian J. of Phycol. Vol. 20, 2019 


\section{Identification using amplification of 16SrRNA gene of Anabaena}

The results of prokaryotic identification using 16SrRNA showed that there is a single band at $515 \mathrm{bp}$. This band was sequenced and indicated that the sample was A.torulosa. The percent of similarity was $98 \%$ comparing to the data on NCBI.

\section{RAPD-PCR and electrophoretic analysis}

A total of 19 bands were amplified among four different treated $A$ .torulosa compared to control by using four RAPD primers (OPA-11, OPA-13, CRA-22 and Hip-TG). Table (3) indicated the sequence, melting temperature (Tm) and GC\% which characterized the used four primers.

Table (3) Codes, sequences, Ta and GC\% for the four random primers used in RAPD- PCR analysis

\begin{tabular}{|l|c|c|c|c|}
\hline No. & Primer name & Primer sequence & Ta & GC\% \\
\hline 1 & OPA-11 & CAATCGCCGT & 32 & 60 \\
\hline 2 & OPA-13 & CAGCACCCAC & 34 & 70 \\
\hline 3 & CRA-22 & CCGCAGCCAA & 34 & 70 \\
\hline 4 & Hip-TG & GCGATCGCTG & 34 & 70 \\
\hline
\end{tabular}

These amplifications were showed in Plate (1) and Table (4) which illustrated the bands from the different treatments through the different four primers comparing with control. The total bands are 19,8 of them are polymorphic with polymorphism percentage of $43.75 \%$ and 11 are monomorphic bands. So, the later bands could be specific bands of genus of Cyanophyta.

There were unique bands appeared only in control Anabaena comparing with all treatments such as band at $60 \mathrm{bp}$ with Hip-TG primer and band at $230 \mathrm{bp}$ with CRA-22 primer, these explain that these bands quite sensitive to any change 
in media. Also, there is a new band appeared only with the different treatments and not exists at control like the one at $150 \mathrm{bp}$ with primer Opa-13, these indicate there were some change happened with DNA. The most affected treatments were different sodium chloride concentration (T3-T7) and combined stress (T8) by appearing and disappearing some bands, these mean that salinity can affect directly on the DNA and proteins which can affect directly on physiological reaction like oil percentage and fatty acid ratio.

Table (4) Polymorphism and data analysis of the used primers with A. torulosa under different stress conditions

\begin{tabular}{|c|c|c|c|c|c|c|c|c|}
\hline Treatments & $\begin{array}{c}1 \\
\text { Control }\end{array}$ & $\begin{array}{c}2 \\
(50 \% \mathrm{~N})\end{array}$ & $\begin{array}{c}3 \\
(50 \% \mathrm{P})\end{array}$ & $\begin{array}{c}4 \\
200 \\
\mathrm{mMNaCl}\end{array}$ & $\begin{array}{c}5 \text { combined } \\
\text { stress 50\% } \\
\mathrm{N}+(50 \% \mathrm{P}+ \\
200 \mathrm{mM} \\
\mathrm{NaCl})\end{array}$ & $\begin{array}{c}\text { Total } \\
\text { no. of } \\
\text { bands } \\
\text { for } \\
\text { each } \\
\text { primer }\end{array}$ & $\begin{array}{c}\text { Total no. of } \\
\text { polymorphic } \\
\text { bands for } \\
\text { each primer }\end{array}$ & $\begin{array}{c}\text { Polymorphism } \\
\text { percentage (\%) }\end{array}$ \\
\hline OPA-11 & 3 & 4 & 4 & 3 & 3 & 5 & 1 & 20 \\
\hline OPA-13 & 4 & 4 & 4 & 3 & 2 & 4 & 3 & 75 \\
\hline CRA-22 & 5 & 4 & 4 & 4 & 4 & 5 & 3 & 60 \\
\hline Hip-TG & 5 & 2 & 2 & 4 & 4 & 5 & 1 & 20 \\
\hline
\end{tabular}




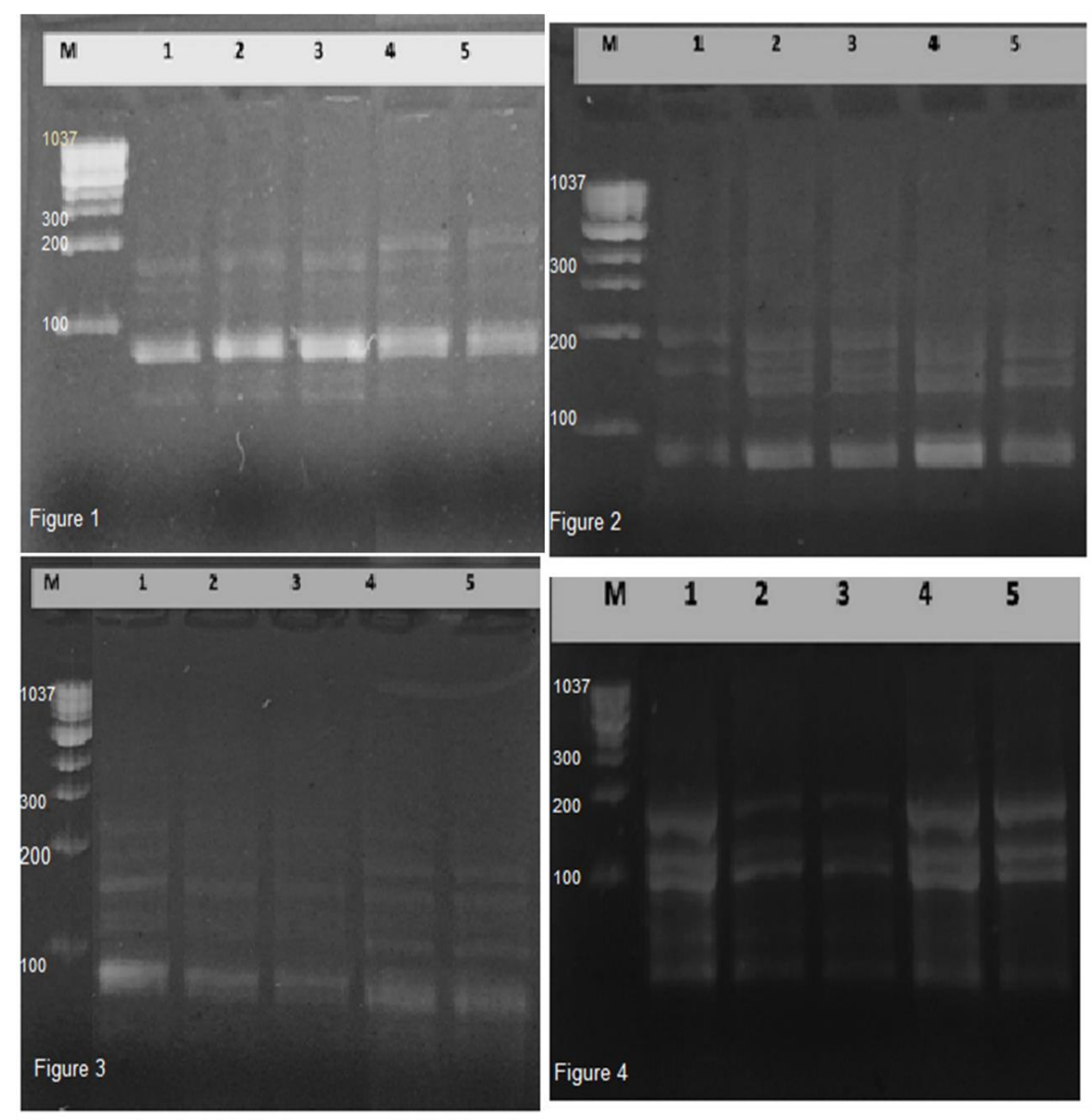

Plate (1): Agarose gel electrophoresis of four random primers under different stress conditions of $A$. torulosa. A: tested with primer OPA-11, B: tested with primer OPA13, C: tested with primer CRA-22, D: tested with primer Hip-TG. Each figure contains 6 lanes; lane:M: Marker (in all figures), lane 1: control $A$. torulosa, Lane2: A. torulosa treated with $50 \% \mathrm{NaNO}_{3}$, lane 3: A. torulosa treated with50\% $\mathrm{K}_{2} \mathrm{HPO}_{4}$, lane 4: A. torulosa treated with $200 \mathrm{mMNaCl}$, lane 5: A. torulosa treated with $50 \%$ $\mathrm{NaNO}_{3}+50 \% \mathrm{~K}_{2} \mathrm{HPO}_{4}+200 \mathrm{mM} \mathrm{NaCl}$. 
Figure (5) illustrate the relationship between the control of Anabaena and the different stress treatments based on UPGAMA phylogenetic tree method. As the treatments $50 \% \mathrm{P}$ and $200 \mathrm{mMNaCl}$ are closer together on their effect so they were separated in the same clade. The treatments $50 \% \mathrm{~N}$ and combined stress are closely on their effect and nearly related to control Anabaena.

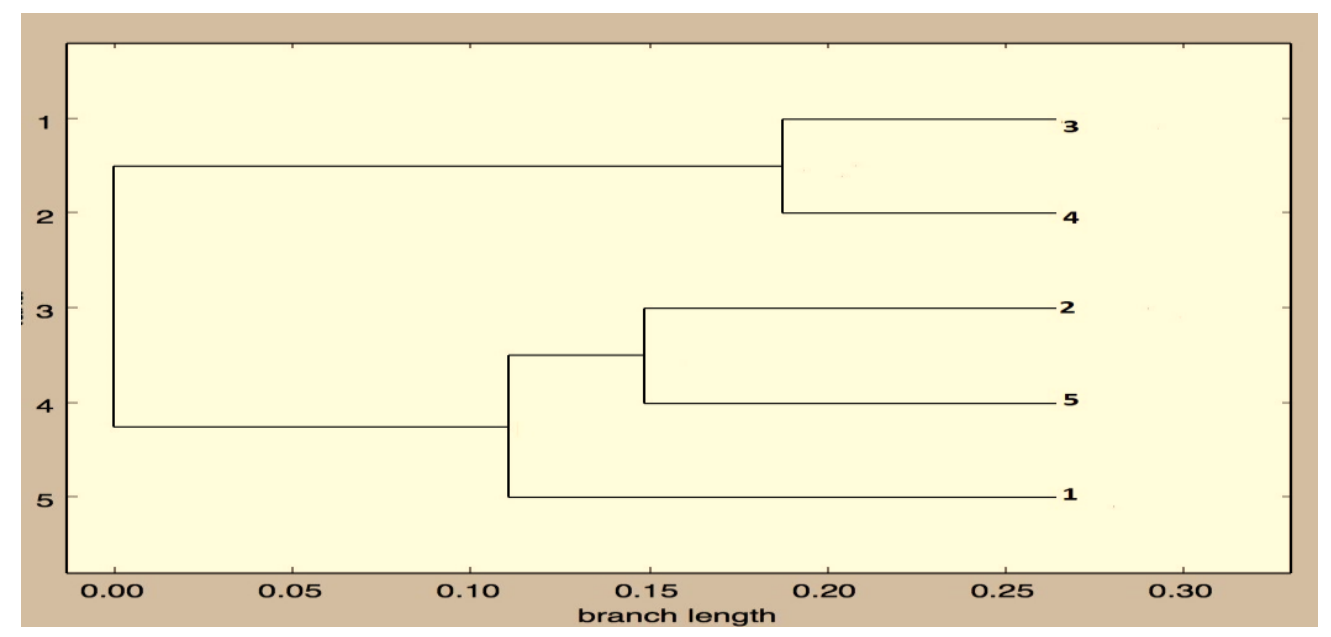

Figure (5) UPGAMA phylogenetic tree of A.torulosa under different stress conditions, 1:control, 2: A. torulosa treated with 50\% $\mathrm{NaNO}_{3}, 3:$ A. torulosa treated with50\% $\mathrm{K}_{2} \mathrm{HPO}_{4}$, 4: A. torulosa treated with $200 \mathrm{mMNaCl}$, 5: A. torulosa treated with $50 \% \mathrm{NaNO}_{3}+50 \% \mathrm{~K}_{2} \mathrm{HPO}_{4}+200 \mathrm{mM} \mathrm{NaCl}$.

The relation between results obtained from the result of oil content (biofuel production) and RAPD cluster analysis indicated that A. torulosa with $50 \% \mathrm{P}$ and $200 \mathrm{mMNaCl}$ stresses have significant effect. That significance in oil production may be related to appear of new band at $160 \mathrm{bp}$ with OPA-11 primer. Also, appear of two new bands at 130 and $190 \mathrm{bp}$ with CRA-22 primer. 
The low production of oil content from the treatments of $50 \% \mathrm{~N}$ and combined stresses was also indicated in the cluster analysis resulted from RAPD bioassay. The control is separated in a clade due to disappear of band at $150 \mathrm{bp}$ with OPA-13 which may explain the low oil content.

\section{Discussion}

The lipid production by Anabaena gave $15.53 \%$ these rates are similar to or exceed the previously recorded rates for related species. Cordiero et al. (2017) reported that the lipid production by different Microcystis species ranged from 14.3 to $40.5 \%$ so that cyanobacteria constitute a raw material for biofuel production. The changes in the nitrogen and phosphorus contents in BG11 medium affected the lipid yield. Results of this study are corroborated by those of Salem et al.(2013), they found that the oil content of Phormidium increased $40 \%$ in media with $50 \%$ nitrogenand $61.27 \%$ in mediawith $50 \%$ phosphorus

The nitrogen stress on A. torulosa gave the lowest increase that may be due to its capability to diazotrophic growth, which means that these strains don't need a nitrogen source in the culture medium for growth (Whitton and Potts, 2012). The increase in lipid content at higher $\mathrm{NaCl}$ concentration may be due to adaptation under stress conditions which help in accumulation of lipid content and these results are in accordance with the finding of Takagi et al. (2006) in Dunaliella cells, Salem et al. (2013), find $85.95 \%$ increase in oil content of Phormidium sp. treated with $100 \mathrm{mMNaCl}$. Battah et al. (2014) also reported that high salinity is directly related to minimum growth and over production of lipids.

Methyl linoleate (unsaturated fatty acids) in our results recorded 56-57 in control and stressed culture, linoleate is classified as a biodiesel due to its long methyl ester chain and is used as a fuel in standard diesel engines. This finding is in accordance with Sallal et al. (1990) who reported that, in lipids of $A$. cylindrical, palmitic, linoleic and linolenic acids were predominant. Also Salem et al. (2013) showed that palmetic, stearic, oleic, linolenic and linoleic acids were the most common fatty acids in Phormidium sp. on the other side Gazal et al (2016) found that in Anabaena laxa, Anabaena fertilissima linoleate not exceeds $1 \%$. 
As a result of this study it was suggest that, despite the inherent problems, taxonomic identification of cyanobacterial species could be improved through a combination of morphological and molecular analysis, taking into consideration both wild and cultured material. Valerio et al. (2009) and Keshari et al. ( 2015) support our results. Many molecular markers were used to differentiate between different strains of Anabaena or the effect of different treatments looks like our study. Prasanna et al. (2006) used molecular markers as LTRR and STRR for characterization of different 30 strains of Anabaena. Some people used RAPD analysis for differentiation among strains of cyanobacteria; Shalini et al. (2007), Perumal et al. (2009) and Chakdar and Pabbi, (2017).

The difference in bands resulted from using different primers explained as a follows: Generally; the different stress treatments resulted from deficiency of different elements so these treatments may cause some mutations which made change in the DNA sequence and follow change of protein. All these made change in algal physiological behavior. Some polymorphic and unique bands were appeared and disappeared, so it might be attributed to effect of different treatments of nitrogen, phosphorus content and salinity stress which affecting the vital physiological pathways.

The use of UPGAMA cluster analysis agreed with Prasanna et al. (2006) who used this relation analysis to differentiate a set of 30 Anabaena strains, isolated from diverse geographical regions of India.

The low production of oil content from the treatments of $50 \% \mathrm{~N}$ and combined stresses was also indicated in the cluster analysis resulted from RAPD bioassay. To sum up, the different stresses of the treated A. torulosa lead to variation in the oil content and so biofuel production. All that was explained genetically based on RAPD-PCR bioassay. This was obvious in the 50\%P stress which gave the highest amount of oil content.

\section{Acknowledgment}

The authors would like to express their thanks for the support of production of biofuels from algae and plants project (Implemented and funded by Helwan Univ. A18252). 


\section{References}

Allen, M.M. (1968).Simple conditions for growth of unicellular blue-green algae. Journal of Phycology, 4:1-4.

Battah, M.G.; El-Ayoty, Y.M.;Esmael, A.E. and Abd El-Ghany, S.E. (2014) Effect of different concentrations of sodium nitrate, sodium chloride and ferrous sulphate on the growth and lipid content of Chlorella vulgaris. Journal of Agricultural Technology, 10 (2): 339-353.

Chakdar, H., and Pabbi, S. (2017) A comparative study reveals the higher resolution of RAPD over ARDRA for analyzing diversity of Nostoc strains. 3 Biotech, 7(2): 125

Chio, H.J.;Joo, J.H.;Joo, H.K.; Wang, P.; Jang, S.K. and Han, M.S. (2018) Morphological characterization and molecular phylogenetic analysis of Dolichospermum hangangense (Nostocales, Cyanobacteria) sp. nov.from Han River, Korea, Algae.,33(2): 143-156.

Cordeiro, R.S.;Vaz, I.C.D.;Magalhães, S.M.S. and Barbosa, F. A.R. (2017) Effects of nutritional conditions on lipid production by cyanobacteria. Anais Da Academia Brasileira De Ciências, 89(3): 20212031.

Elsayed, A.B. and Salem, Olfat M.A. (2016) Effect of different light wave lengths on the growth and oil content of Chlorella vulgaris, Egyptian Journal of Phycology, 17: 17-32

Halim, R.; Gladman, B.; Danquah, M.K.and Webley, P.A. (2011) Oil extraction from microalgae for biodiesel production, Bioresource Technology, 102(1): 178-85.

Hu, Q.;Sommerfeld, M.; Jarvis, E.;Ghirardi, M.; Posewitz, M. and Darzins, M.(2008) Microalgal triacylglycerols as feedstocks for biofuel production: perspectives and advances. Plant Journal, 54(4): 621-639.

Keshari, N.; Kumar S.D. and Adhikary S.P. (2015). Identification of cyanobacterial species with overlapping morphological features by $16 \mathrm{~S}$ rRNA gene sequencing. European journal of phycology, 50(4): 395-399. 
Lyra, C.;Hantula J.;Vainio E.;Rapala J.; Rouhiainen L. andSivonen K. (1997). Characterization of cyanobacteria by SDS-PAGE of whole cell proteins and PCR/RFLP of the 16S rRNA gene. Archives of Microbiology., 168 (3): 176-184.

Nirupam, B.;Gour G.S.;SudeshnaS.R.;Nilofer K.;Ramkrishna S.;SanjitK.A.; Prasad R.B.N. and Ruma P. Mapping (2012). Algae of Sundarban Origin as Lipid Feedstock for Potential Biodiesel Application. Journal of algal biomass utilization.3 (2): 42- 49.

Okore, K.;Nwaehiri, L.; Mbanefo,O.;Ogbulie, T. and Ogbuka, I.(2017). The use of random amplified polymorphic DNA (RAPD) to study the genetic variation of biosurfactant producing bacteria. Academic Journal of Science.7(3): 267-286.

Perumal, G.M.;Ganesan, V. and Anand, N. (2009). Identification and phylogenetic analysis of filamentous Cyanobacteria using random amplified polymorphic DNA (RAPD) fingerprinting. African Journal of Biotechnology, 8(6): 974-978.

Prasanna, R.; Kumar, R.;Sood, A.;Prasanna, B.M. and Singh, P.K. (2006).Morphological, physiochemical and molecular characterization of Anabaena strains. Microbiological Research, 161: 187-202.

Rodolfi, L.;Chini, Z.G.;Bassi, N.;Padovani, G.;Biondi, N.;Bonini，G. and Tredici, M.R. (2009). Microalgae for oil: strain selection, induction of lipid synthesis and outdoor mass cultivation in a low-cost photobioreactor., Biotechnology and Bioengineering., 102(1): 100-120.

Rogers, S.O. and Bendish, A.J. (1998).Extraction of DNA from plant tissues. In: Gelvin SB, Schilperoort RA (eds). Plant molecular biology manual. Kluwer Academic Publishers, Dordrecht/Boston/London, 1-10.

Rozes, N.;Garbay, S.;Denayrolles, M. and Lonvaud-Funel, A. (1993).A rapid method for the determination of bacterial fatty acid composition. Letters in Applied Microbiology, 17(3): 126-131.

Salehzadeh, A. and Naeemi, A.S. (2017).Biodiesel production from Anabaena variabilis cyanobacterium. Indian Journal of Geo Marine Sciences, 46 (2): 385-390. 
Salem, M.A.O.; El-Ardy, O. and Abd El-Rahman, M. A. (2013). Effect of nitrogen and phosphorus concentrations in growth medium and Salt stress on growth, lipid content, and biodiesel producing ability of microalgae, Egypt.J.Bot. $3^{\text {rd }}$ international conf.17-18 April, Helwan Univ.219-233.

Sallal, A. K.; Nimer, N. A. and Radwan, S. S. (1990).Lipid and fatty acid composition of freshwater cyanobacteria, Journal of General Microbiology, 136: 2043-2048.

Shalini, A.;Tiwari, S.; Gupta, R.K.;Pabbi S. and Dhar, D.W. (2007). Protocol optimization for RAPD in cyanobacteria. Indian Journal of Biotechnology, 6: 549-552.

Shuaib, M.; Zeb, A.; Ali, Z.; Ali, W.; Ahmad, T. and Khan, I.(2007). Characterization of Wheat Varieties by Seed Storage Protein Electrophoresis. African journal of biotechnology, 6: 497-500.

Takagi, M.; Karseno, S. and Yoshida, T. (2006).Effect of salt concentration on intracellular accumulation of lipids and triacylglyceride in marine microalgae Dunaliella cells. Journal of Bioscience and Bioengineering, 101(3): 223-226.

Tang, D.; Han, W.; Li, P.; Miao, X.andZhong, J. (2011). CO $\mathrm{CO}_{2}$ biofixation and fatty acid composition of Scenedesmusobliquus and Chlorella pyrenoidosa in response to different $\mathrm{CO}_{2}$ levels, Bioresource Technology.102 (3): 3071-3076.

Valerio, E.; Chambel, L.;Paulino, S.;Faria, N.; Paulo, P. and Rogério T. (2009).Molecular identification, typing and traceability of cyanobacteria from freshwater reservoirs.Microbiology,155: 642-656.

Wacklin, P.; Hoffmann, L. and Komárek J. (2009). Nomenclatural validation of the genetically revised cyanobacterial genus Dolichospermum (Ralfs ex BornetetFlahault) comb. nova, Fottea.9 (1): 59-64.

Whitton,B.A. and Potts, M. (2012). Introduction to the Cyanobacteria. In: The ecology of cyanobacteria II. Their diversity in space and time (Whitton, B.A. editor).Springer, Dordrecht.1-13. 


\section{إنتاج الاهون والار اسات الجزيئية لطحلب Anabaena torulosa معامل بأنواع مختلفة من الإجهاد}

\section{ألفت معتمد عبد الحميد سالم' ، إبتسام عبد الغنى حماد' ، فاطمة أشرف بليع'، ناجى على عبد

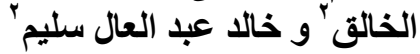

$$
\text { | - قسم النبات والمبكروبيولوجى_ كلية العلوم -جامعة حلوان_القاهرة }
$$

تمت دراسة إنتاج الدهون من حيث نسبة الزيت وتكوين الأحماض الدهنية من طحلب

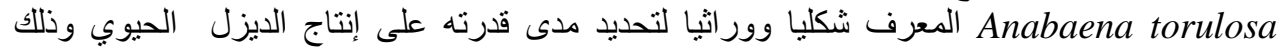

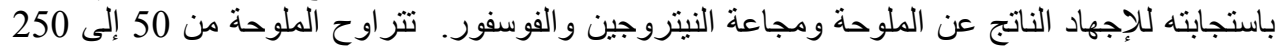

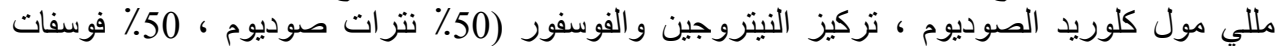

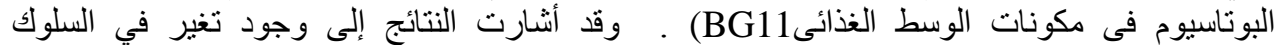

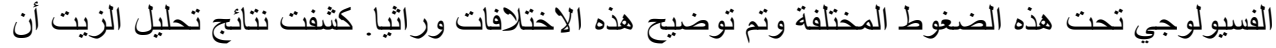

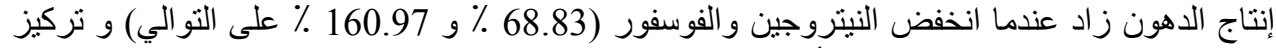

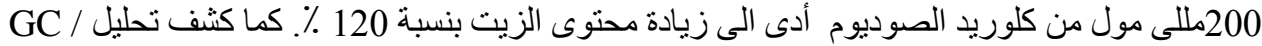

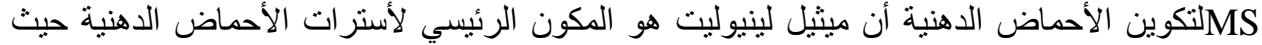

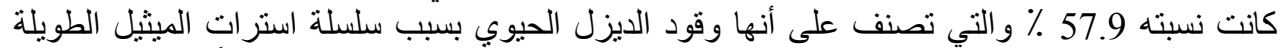
وتستخدم أيضا كوقود في محركات الديزل القياسية. تم توضيح كل هذه النتائج وراثياً باستخدام تقنية

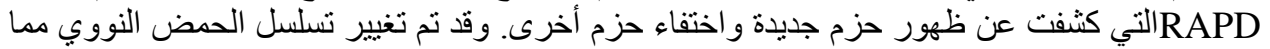

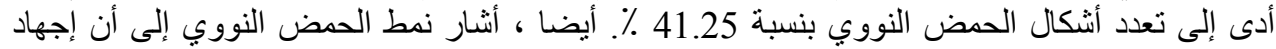

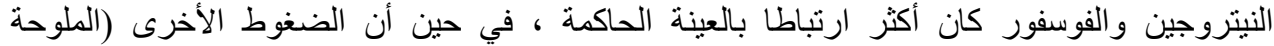

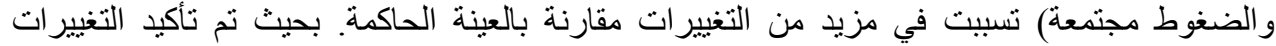
الفسيولوجية الناتجة عن الإجهاد ور اثيا. 